\title{
OBSERVATIONS ON THE PATHOLOGY OF ACUTE RHEUMATISM AND RHEUMATOID ARTHRITIS*
}

\section{By DOUGLAS H. COLLINS}

IT is not possible in a short paper to present any comprehensive survey of the pathology of these two important diseases, but observations and experiments in recent years have led to the formulation of new ideas about the nature of rheumatic disease, and it is therefore appropriate to discuss briefly some of these ideas and their arguments in a critical manner.

An important advance in the study of acute rheumatism has been the recognition of a certain basic pattern of elementary tissue changes in the lesions of the disease. Four simple pathological phenomena participate in these lesions-exudation, mesenchymal proliferation, connective tissue degeneration andoc leucocytic infiltration. Rheumatism affects connective tissues which are not highly differentiated and which are capable of only a limited range of types of reaction, therefore no one of these phenomena can be considered as specific to rheumatism, but, combined together in varying proportions, they lend a general histological character to acute rheumatism, which gives support from the pathological aspect to the already definite clinical conception of the individuality of the disease.

Most attention has been focussed upon the connective tissue degeneration to which the term "fibrinoid degeneration" or "fibrinoid change" has been given. Talalajew (1929) and Klinge (1933), in particular, have emphasised this change, which they have described in great detail. Fibrinoid swelling of the collagen bundles of mature fibrous tissue, associated with fibrinous exudation into the tissue spaces (the mucinous odema of Talalajew), gives rise to a granular focus of necrosis which takes

* Based on a paper read in the discussion on the Etiology of Acute Rheumatism and Rheumatoid Arthritis of the Section of Pathology, 106th B.M.A. Annual Meeting, Plymouth, July, 1938. 
fibrin stains partially and possesses a fibrillar reticulated structure. Many now believe that fibrinoid degeneration is the primary tissue change in rheumatism, and that proliferation of mesenchymal cells and invasion of leucocytes occur secondarily around the necrotic focus, but Aschoff (1904) and some other early writers thought that the degeneration follows cellular proliferation. The two processes proceed hand in hand, and it is often impossible in human tissues to express an opinion on which preceded the other. Aschoff (1938) appears still unconvinced about the course of events leading to the formation of the rheumatic node. My own observations on the subcutaneous nodule in rheumatoid arthritis (Collins, 1937) persuade me to believe that, in this structure at least, proliferation of connective tissue precedes degeneration. None the less, it is true that fibrinoid change is a prominent and characteristic feature of the rheumatic lesion. It is true also that fibrinoid change takes place in tissues as part of the Arthus phenomenon of local anaphylaxis, and that it appears to be a basic type of tissue reaction in states of hypersensitivity. On the similarities of the morbid histology of rheumatism and the experimentally produced lesions in hypersensitive animals it has been argued that rheumatism is an allergic manifestation. This may be so, but it must be remembered that fibrinoid change may also be a simple and general type of degeneration in a simple and common tissue. Experimental work by $\mathrm{Wu}(1937)$ and Werner (1938) indicates that fibrinoid swelling of collagenous connective tissue can appear under certain non-specific stimuli whether or not the tissues are in a state of hypersensitivity. Experimental work on scurvy, with or without the addition of infection (Rinehart, 1936; Schultz, 1936), shows us yet another factor which will stimulate connective tissues to react in ways more or less resembling the lesions of rheumatic fever. As we become more adept at the microscopical analysis of connective tissue lesions in man we shall probably find that fibrinoid change is not confined to the rheumatic state. Indeed, anyone who has studied the pathology of human connective tissues, or who has taken the trouble to examine such damaged connective tissues as those of ganglia, injured bursæ and so on, will hesitate before interpreting any microscopic connective tissue degenerations as the specific result of a particular form of injury.

The subcutaneous nodules have long been a field for pathological observations in rheumatism. There has been a general 
tendency to consider the nodules in rheumatoid arthritis and acute rheumatism as identical in nature, mainly because of the similarity in the elementary tissue changes. I have elsewhere (Collins, 1937) put forward my reasons for not being prepared to presume the identity of rheumatic fever with rheumatoid arthritis simply on the grounds of a certain similarity of reaction in a relatively undifferentiated tissue whose reactive potentialities are limited. There are divergences in the subsequent growth of these two types of nodules, just as there are even greater divergences in the clinical course of the two diseases. Even the remarkable picture of a focus of connective tissue fibrinoid degeneration surrounded by a corona of fibroblasts may not be specific to the rheumatic lesion (Fig. 1). A similar formation is met with in the dermis in granuloma annulare (Fig. 2), as Goodman and Ketron (1936) have pointed out-a skin disease which, though possibly associated with streptococcal infection or with tuberculosis (Halliwell and Ingram, 1935), has no clinical connection with rheumatism.

The tissue changes in acute rheumatism are frequently widespread throughout the body. Important amongst these diffuse lesions are those which concern the arteries. Rheumatic arteritis affects all the coats of the vessel and any combination of the following changes may be observed: deposition of amorphous fibrinoid material in the intima, which later becomes replaced by fibrous tissue; degeneration of the media with fragmentation of the elastic laminæ; proliferation of fibrous tissue cells loosely arranged concentrically around the adventitia; infiltration of all coats with polymorphs, eosinophils, lymphocytes, or plasma cells (Fig. 3). The appearance of this arteritis sometimes closely resembles periarteritis nodosa, but it is said that thrombosis and aneurysm formation very seldom occur in rheumatic arteritis (Von Glahn and Pappenheimer, 1926). Polyarteritis has been observed frequently in rheumatic fever, but in rheumatoid arthritis the vascular lesions seem to be confined to the joints or subcutaneous nodes (Fig. 4).

Sometimes at death in a fulminating case of rheumatic fever there is a diffuse interstitial infiltration of the myocardium with polymorphs in the absence of secondary infection. Polymorphs also are present in the synovial effusion both in rheumatic fever and in rheumatoid arthritis, but the exudation of fluid is so great that the effusion, though turbid, is never truly purulent. 
The histological changes in the synovial tissue of joints in rheumatic fever consist of odema, congestion, slight leucocytic invasion and sometimes fibrinoid degeneration of the deeper tissues, together with occasional foci of proliferated large mesenchymal cells which may bear some slight resemblance to the myocardial Aschoff node. In rheumatoid arthritis the inflammatory proliferation of synovial tissue is much more pronounced, and a particular feature is the growth of large foci of lymphocytes or plasma cells (Fig. 5), but it is doubtful if even this implies more than a general type of reaction of this tissue to any chronic inflammation. Swift (1936) has observed an identical appearance in the tendon sheath lining in traumatic tenosynovitis (Fig. 6).

Too much attention has been paid in this country to identifying acute rheumatism with rheumatoid arthritis. So many of the pathological data which are supposed to relate the two diseases are of doubtful specificity. The grosser pathological appearances and the clinical features are quite different, and although we cannot deny the possibility of a relationship between them it seems safer, at present, to regard them as independent. For the investigator this is certainly the wiser course; he need not then find explanations of ætiology to suit both.

In rheumatic fever the histologist can see phenomena which probably indicate the widespread action of a viable infective agent or of its soluble products, together with exudative phenomena resulting from tissue hypersensitivity produced as a phase of the infective disease (Aschoff, 1938). In rheumatoid arthritis the disease is more clearly localised to the joints and to the subcutaneous tissues which are exposed to trauma, and in this disease an overwhelming infection or a fulminating course rarely supervenes.

Rheumatic fever is pathologically and clinically so well defined a disease that we are almost bound to suppose that it has only one primary cause. The assumption of a uniform specific ætiology for all cases of rheumatoid arthritis is less justified, though we may believe this to be the case in the majority of instances. But since various specific infections-for example, Malta fever, tuberculosis, and gonorrhœa-can occasion a polyarthritis, the differentiation of which is only a matter of recent experience, we should not be too eager to assume a common origin for all those cases which to-day we call of unknown ætiology.

A variety of micro-organisms have been grown from the joints in rheumatoid arthritis, organisms which, for the most 
Fig. 1.-Rheumatoid Arthritis.

Subcutaneous nodule in female, aged forty-two, with rheumatoid arthritis for five years. Characteristic zone of fibrinoid degeneration surrounded by a palisade of fibroblast-like cells with light lymphocytic infiltration of surrounding connective tissue. (H. and E., $\times 75$.)

\section{Fig. 2.-Granuloma Annulare.}

Focus of connective tissue degeneration in dermis surrounded by palisade of fibroblast-like cells with light lymphocytic infiltration. The appearance is remarkably similar to Fig. 1. Patient was a female aged twenty-eight, and the tissue was removed from a patch of granuloma annulare on the back of the hand which had been present for one year. There was no evidence or history of any form of rheumatism. (H. and E., $\times 50$.)

\section{Fig. 3.-Arteritis in Rheumatic Fever.}

A vessel in the first part of the aorta from a female, aged twenty, who died in a relapse of rheumatic fever, the first attack being seven years earlier. Fibrous tissue replacement of fibrinoid deposit in the intima; breakage of the elastic lamina; new fibrous tissue cells loosely arranged around the vessel causing gross thickening, and diffuse infiltration of all parts of the vessel with polymorphs and lymphocytes. (Elastica stain, $\times 50$.)

\section{Fig. 4.-Rheumatoid Arthritis.}

Endarteritis of small vessel in synovial membrane of knee from female, aged fifty-seven, who had rheumatoid arthritis for seven years. Note also proliferation of synovial lining cells and infiltration with lymphocytes and plasma cells. (H. and E., $\times 135$.)

Fig. 5.-Rheumatoid Arthritis.

Collection of lymphoid cells in synovial villus of knee-joint in same patient as Fig. 4. (H. and E., $\times 45$.)

Fig. 6.-Traumatic Tenosynovitis.

Collection of lymphoid cells in synovial villi of tendon sheath in chronic traumatic tenosynovitis from female aged thirteen years. There was no evidence of rheumatoid arthritis or of rheumatism. (H. and E., $\times 60$. 


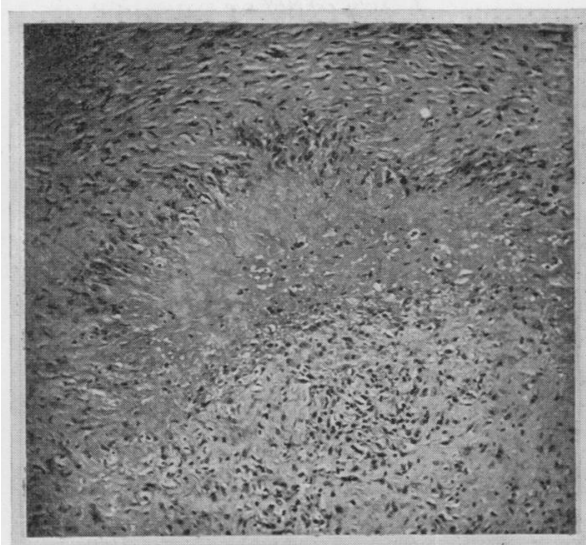

Fig. I

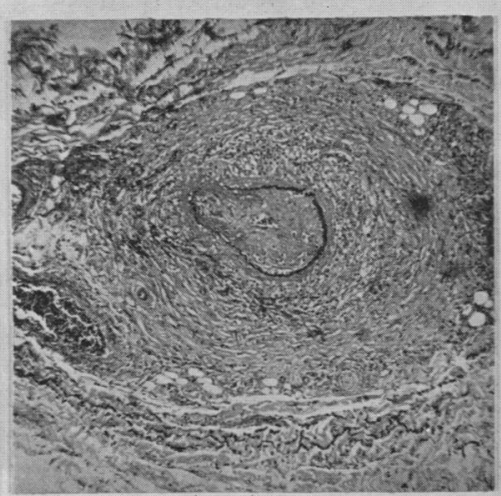

Fig. 3

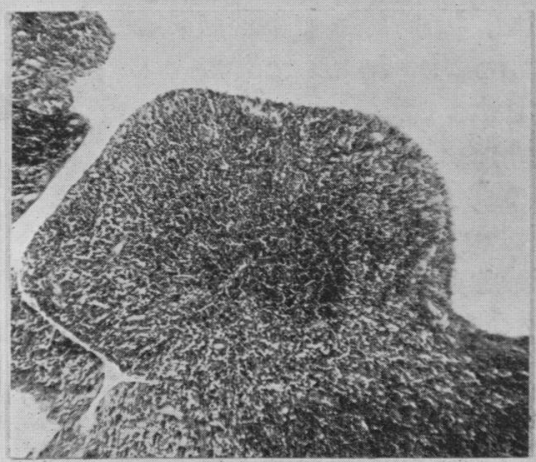

Fig. 5

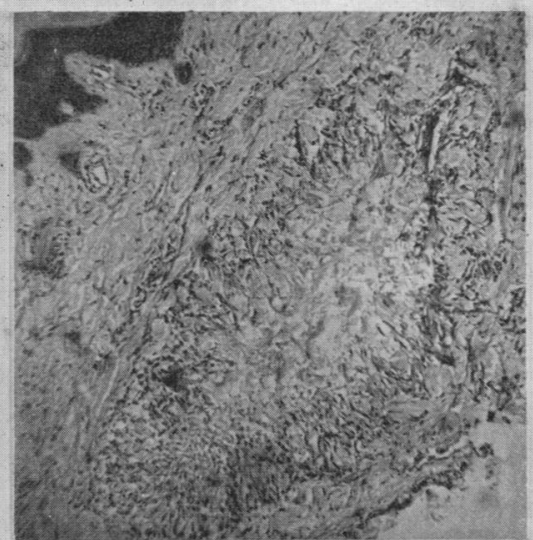

Fig. 2

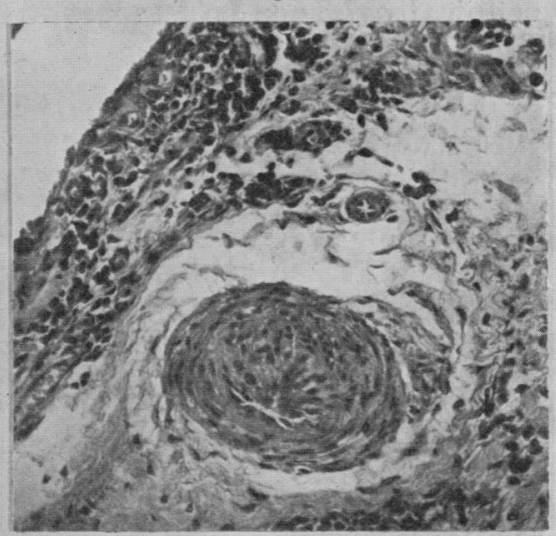

Fig. 4

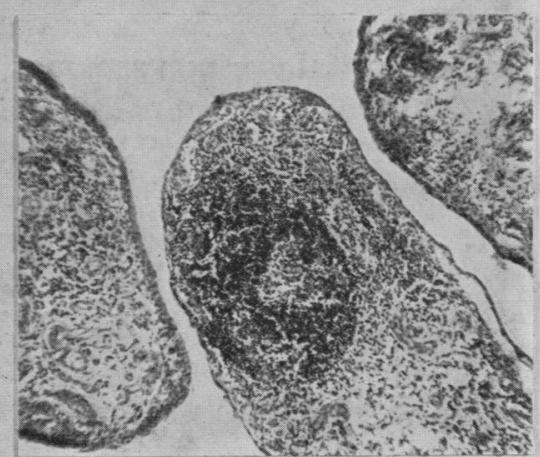

Fig. 6

윽

름

옹

要

음

๙ั

N

స

श्व

0 
part, may well have been contaminants. A far greater number of joint cultures have been negative. Aerobic cultures of some eighty joint fluids in my own cases of rheumatoid arthritis have been invariably sterile. For these reasons, actual bacterial infection of the joints is now generally denied. But can we be sure that the joint tissues in the early stages of the disease are always sterile? In my own experience the joint fluid in rheumatoid arthritis, on account of its content of polymorphs, is highly bactericidal, but it has been practically impossible to make examination of the joint tissues in the early disease.

Gräff (1936) is one of the few who claim to have demonstrated cocci in the synovial tissues. It is important to attempt to repeat this work of Gräff's, because the conception of rheumatoid arthritis as a metastatic infection from a focal point of entry has much clinical evidence to support it and has not yet been disproved pathologically.

In rheumatoid arthritis, as in rheumatic fever, the disease is at some phase possibly associated with a tissue hypersensitivity which may explain some of the exudative and degenerative features. The repair reactions of the connective tissue play an important rôle in the production of the disabilities of rheumatoid arthritis, as one would expect from the chronicity of the disease, and exposure to trauma is an important localising factor.

In conclusion, I feel that the experimental production of various microscopic connective tissue changes should not be too readily accepted as having a direct bearing on the problem of rheumatism. This type of work is of great importance in enlightening us on the potentialities of connective tissue in reacting to various noxious agents, but the ultimate aim of experimental work on rheumatism must be to reproduce a disease which is as closely analogous in all its objective phenomena to rheumatism as possible. The granulomatous lesions of the heart valves, of the subcutaneous tissues, and of the peripheral arteries, together with the hæmorrhagic and infiltrative lesions of the early disease, are more convincing criteria of acute rheumatism than are the minutiæ of tissue damage. It is probable, too, as I have attempted to show, that similar histological features may occur in unrelated diseases. Modern pathology is becoming increasingly full of such anomalies. More particularly is this likely to be so when we are dealing, as in the case of rheumatism, with simple connective tissues. If, therefore, experienced clinicians are 
prepared to dissociate acute rheumatism from rheumatoid arthritis, the pathologist is not yet in a position to dispute them. Bacteriologists, on the other hand, may one day, with fuller knowledge of the pathogenicity of certain common organisms, be in this position.

Bacteriological researches in both diseases seem to incriminate the streptococcus. The histological findings, though unlike those of any hitherto proved streptococcal disease, do not weigh against the possibility of a streptococcal ætiology. The gross findings are, for the most part, without precedent in our pathological knowledge, and the protean capabilities of the streptococcus in production of disease are only just beginning to be explored.

Successful investigation of the very complicated problems of acute rheumatism and rheumatoid arthritis depends upon the closest co-operation between pathologist, bacteriologist and clinician. The efforts of any one of these without the help of the others are likely to be misdirected or to lead to false conclusions.

The author is gratefully indebted to Dr. Walker E. Swift of the New York Orthopædic Hospital and Dispensary for material from cases of tenosynovitis, including that from which Fig. 6 was made; to Dr. F. F. Hellier of Leeds for material from cases of granuloma annulare, including that illustrated in Fig. 2; and to Dr. J. Alex. Thomson of Harrogate for the photomicrographs.

\section{REFERENCES}

AschofF, L. (1904): Verh. dtsch. path. Ges., H. 2, 46.

AschоғF, L. (1938): "A Survey of Chronic Rheumatic Diseases " (London), p. 217.

Collins, D. H. (1937): Journ. Path. and Bact., xlv. 97.

Goodman, M. H., and Ketron, L. W. (1936): Arch. Dermatol. and Syphilol., xxxiii. 473.

GR ÄFF, S. (1936): "Rheumatismus und rheumatische Erkrankungen." Berlin.

Halliwell, E. O., and Ingram, J. T. (1935): Brit. Journ. Dermatol. and Syph., xlvii. 319.

KLINGE, F. (1933): "Der Rheumatismus." Munich.

Rinehart, J. F. (1936): Journ. Lab. and Clin. Med., xxi. 597.

Schultz, M. P. (1936): Arch. Path., xxi. 472.

SwIFT, W. E. (1936): Personal communication.

TalalaJEW, W. T. (1929): Klin. Wschr., i. 124.

Von Glahn, W. C., and Pappenhermer, A. M. (1926): Amer. Journ. Path., ii. 235.

Werner, M. (1938): Arch. f. path. Anat. u. Phys., ccci. 552.

Wu, T. T. (1937): Ibid., ccc. 37 ?. 